\title{
DEWELOPER I NABYWCA LOKALU MIESZKALNEGO LUB DOMU JEDNORODZINNEGO JAKO STRONY UMOWY DEWELOPERSKIEJ
}

\author{
DEVELOPER AND BUYER AS PARTIES OF PROPERTY DEVELOP- \\ MENT CONTRACT
}

\begin{abstract}
Streszczenie: Autor w swoim artykule omówi kwestię stron umowy deweloperskiej. Postara się przedstawić podstawę prawną dotyczącą przedmiotu wykładu. Omówi także prawa i obowiązki strony umowy deweloperskiej, wynikające zarówno z tzw. ustawy deweloperskiej, a także z innych aktów prawnych. Twórca przedstawi uprzywilejowaną pozycję nabywcy w stosunku do dewelopera w kontekście ochrony praw strony kontraktu, a także poruszy problematyczną kwestię w przypadku, gdy zarówno deweloperem, jak i nabywcą jest przedsiębiorca. W artykule za punkt wyjścia przyjęto przepisy Kodeksu cywilnego, ustawy z dnia 16 września 2011 r. o ochronie praw nabywcy lokalu mieszkalnego lub domu jednorodzinnego (Dz. U. 2011 nr 232 poz. 1377 ze zm.), ustawy z dnia 16 lutego 2007 r. o ochronie konkurencji i konsumentów (Dz. U. Nr 50, poz. 331) oraz innych ustaw..
\end{abstract}

Słowa kluczowe: umowa deweloperska, deweloper, nabywca, konsument

Received: 07.2018

${ }^{*}$ Uniwersytet w Białymstoku
Abstract. The author in his article will discuss an issue of parties to the contract property. He will try to introduce himself the legal grounds concerning the subject of the lecture. He will discuss also rights and obligations of the property party to the contract, resulting both from the so-called property act, as well as from other legal documents. The author will describe the privileged position for the buyer towards the developer in the context of the protection of rights of the side of the contract, as well as will address a debatable issue in the event that an entrepreneur is both a developer, and a buyer. In article author will use Polish Civil Code, Development Contract Law, Competition and Consumer Protection Law..

Key words: property development agreement, developer, buyer, consumer.

Accepted: 09.2018 


\section{Wstęp}

Regulacja ustawowa jasno określa katalog podmiotów umowy deweloperskiej. Zauważalnym jest fakt, że jest to umowa podmiotowo kwalifikowana. Jedną ze stron jest deweloper, który zgodnie z art. 3 pkt 1 ustawy z dnia 16 września 2011 r. o ochronie praw nabywcy lokalu mieszkalnego lub domu jednorodzinnego prowadzi działalność gospodarczą, na podstawie umowy deweloperskiej zobowiązuje się do ustanowienia prawa odrębnej własności lokalu mieszkalnego albo prawa własności nieruchomości zabudowanej domem jednorodzinnym lub użytkowania wieczystego nieruchomości gruntowej i własności domu jednorodzinnego na niej posadowionego stanowiącego odrębną nieruchomość i przeniesienia tego prawa na nabywcę. Drugim podmiotem będącym stroną kontraktu deweloperskiego jest, zgodnie z art. 3 pkt 4 [Ustawa z dnia 16 września 2011 ], osoba fizyczna, która na podstawie tej umowy uprawniona jest do przeniesienia na nią własności lokalu albo domu jednorodzinnego wraz ze wszystkimi prawami z nim związanymi, będąc jednocześnie zobowiązaną do spełnienia świadczenia pieniężnego na rzecz dewelopera.

Autor w swoim artykule zamierza omówić kwestię stron umowy deweloperskiej. Postara przedstawić się podstawę prawną dotyczącą przedmiotu swoich rozważań. Omówi także prawa i obowiązki strony umowy deweloperskiej, wynikające zarówno z tzw. ustawy deweloperskiej, a także z innych aktów prawnych. Następnie zostanie przedstawiona uprzywilejowana pozycja nabywcy w stosunku do dewelopera w kontekście ochrony praw strony kontraktu, a także poruszona problematyczna kwestia w przypadku, gdy zarówno deweloperem, jak i nabywcą jest przedsiębiorca. Za punkt wyjścia przyjęte zostały przepisy Kodeksu cywilnego, ustawy z dnia 16 września 2011 r. o ochronie praw nabywcy lokalu mieszkalnego lub domu jednorodzinnego (Dz. U. 2011 nr 232 poz. 1377 ze zm.), ustawy z dnia 16 lutego 2007 r. o ochronie konkurencji i konsumentów (Dz. U. Nr 50, poz. 331) oraz innych ustaw. Ponadto autor odwoła się do wstępnych projektów tzw. ustawy deweloperskiej, w których zamiast określenia "nabywca” ustawodawca użył słowa konsument. Ostatnim punktem wystąpienia będą potencjalne wnioski prelegenta. 


\section{Deweloper jako strona umowy deweloperskiej}

Samo pojęcie „dewelopera” zapożyczone zostało z języka angielskiego i tłumaczone jest jako „inwestor budowlany” [Adamska-Sałaciak, 2003, 385]. Oryginalna pisownia developer został spolszczona i w takiej formie jest stosowana zarówno w języku potocznym, jak i w literaturze przedmiotu [http://sjp.pwn.pl/szukaj/deweloper.html]. Przed powstaniem definicji legalnej tego terminu próbowano go dookreślić także w projektach ustawodawczych, np. w projekcie ustawy o zasadach finansowania inwestycji mieszkaniowych [Wszołek, 2011, 19-21] oraz w projekcie ustawy o rachunkach powierniczych oraz o zmianie niektórych ustaw [Kohutek, Kuglarz, 2004, 2-3]. W pierwszym z projektów deweloper był definiowany bardzo szeroko, stanowiąc, że może być nim zarówno osoba fizyczna, osoba prawna, jak i jednostka organizacyjna na podstawie art. $33^{1}$ k.c., która miała zobowiązywać się do przeniesienia własności lokalu w ramach przedsięwzięcia budowlanego. Taka definicja pozbawiona była charakteru profesjonalnego po stronie deweloperskiej, gdyż nie było wzmianki o przedsiębiorcy, co zostało uwzględnione $w$ drugim projekcie. Oba terminy odnosity się stricte do rynku budownictwa mieszkaniowego [Goldiszewicz, 2013, 48].

Obecnie obowiązująca definicja ustawowa dewelopera zawiera w sobie odesłanie do art. $43^{1}$ k.c. definiującego przedsiębiorcę i stanowiąc tym samym o istotności tego terminu w tej konstrukcji. Odnosząc się do tej delegacji ustawowej, należy stwierdzić, że deweloperem mogą być osoby fizyczne, osoby prawne oraz jednostki organizacyjne na podstawie art. $33^{1}$ k.c., które we własnym imieniu prowadzą działalność gospodarczą lub zawodową [Strzelczyk, 2013, 133] w związku z przedsięwzięciem deweloperskim. Zatem w tej konstrukcji mamy do czynienia z jasno określonym kryterium podmiotowym, jak i przedmiotowym [Goldiszewicz, 2013, 49], choć w przypadku jednostek organizacyjnych nieposiadających osobowości prawnej, którym ustawodawca nadał zdolność prawną, to kwestia nazewnictwa w doktrynie jest nieidentyczna [Safjan (red.), 2012, 1214-1215]. Kryterium przedmiotowe odnosi się natomiast do działalności gospodarczej lub zawodowej, które są wykonywane w imieniu własnym. Zdefiniowanie działalności gospodarczej należy rozpocząć od art. 3 ustawy z dnia 6 marca 2018 r. (Dz.U. z 2018 r. poz. 
646)- Prawo Przedsiębiorców, wnioskując z definicji legalnej fakt, że terminy działalności gospodarczej i zawodowej nie są tożsame, przez co należy je rozróżniać [Katner, 2014, 6], z założeniem, że działalność zawodowa stanowi podgrupę w stosunku do działalności gospodarczej [Kidyba, 2012, 21], stanowiąc jej szczególną odmianę [Trzaskowski, 2006, 31-32]. Działalność deweloperska stanowi rodzaj profesjonalnej działalności zarobkowej, która wykonywana jest w sposób ciągły i zorganizowany [Gniewek (red.), 2016, 99]. Tym samym pojęcie to dotyczyć będzie także działalności usługowo-budowlanej realizowanej w zakresie przedsięwzięć deweloperskich [Czech, 2013, 33]. Taka działalność cechuje się nierozerwalnością z kryterium przedmiotowym, gdyż nie do pomyślenia jest, żeby przedsiębiorstwo tego nie było przez dewelopera prowadzone [Goldiszewicz, 2012, 50].

Działalność deweloperska niewątpliwie ma charakter zarobkowy. Związane jest to z samym zobowiązaniem nabywcy, jak i roszczeniem dewelopera, których przedmiotem świadczenie pieniężne. Nie ma natomiast wpływu na to fakt, czy poprzez inwestycję deweloperską deweloper ten zysk uzyska, a czy nawet go planuje [Uchwała Sądu Najwyższego z 14 maja 1998 r., sygn. III CZP 12/98, OSNC 1998, nr 10, poz. 151]. Ze względu na taki charakter podmiotami prowadzącymi działalność deweloperską może być każdy, kto spełni przesłankę wymienioną powyżej. Nie ma na to wpływu forma organizacyjna, chyba że przepisy szczególne taką możliwość wyłączają, jak w przypadku spółek partnerskich, których celem jest wykonywanie wolnego zawodu przez wspólników [Kidyba, 2015, 376-378]. Ustawa deweloperska dotyczy każdego podmiotu prowadzącego działalność deweloperską, bez względu na skalę danego przedsięwzięcia [Strzelczyk, 2013, 134]. Nie mają także na to wpływu kwestie formalne w postaci rejestracji przedsiębiorcy w Krajowym Rejestrze Sądowym lub Centralne Ewidencji i Informacji Działalności Gospodarczej [Gliniecki, 2012, 40]. Takie zaniechanie nie stanowi przesłanki o wyłączeniu podmiotu z kręgu definicji ustawowej dewelopera, a tym samym obowiązków ustawowych z tym związanych [Pyziak-Szafnicka (red.), 2014, 454-456].

Przyjmując za definicją legalną, zgodnie z którą deweloper jest przedsiębiorcą, należałoby zauważyć obligatoryjność spełnienia przez ten podmiot obowiązków na niego nałożonych w związku z prowadzoną przez niego dzia- 
łalnością gospodarczą [Goldiszewicz, 2012, 51]. Jednostronnie handlowy charakter umowy deweloperskiej, niewątpliwie połączony z profesjonalizmem strony wykonawczej tego stosunku cywilnoprawnego, skłania do postawienia tezy o dopełnieniu wymogów nałożonych na inwestora deweloperskiego takich jak posiadanie specjalistycznej wiedzy w zakresie swojej działalności oraz zaplecze finansowo-wykonawcze. Do tej grupy można zaliczyć udział osób, które legitymują się szczególnymi kwalifikacjami oraz wykształceniem, związanym z poszczególnymi etapami przedsięwzięcia deweloperskiego (tj. architekt, inżynier budownictwa). Ponadto może zawrzeć umowę o charakterze kompleksowym przenoszącą ciężar wykonawczy całej inwestycji na podmiot zewnętrzny, niezwiązany z przyszłym nabywcą umową deweloperską. W takim przypadku to ten trzeci podmiot, nie biorący czynnego udziału w relacji deweloper-nabywca prawa własności odpowiedzialny będzie za zapewnienie zaopatrzenia logistycznego i wykonawczego związanego z finalnym celem w postaci zrealizowanego przedsięwzięcia deweloperskiego. W innym wypadku deweloper zawiera umowy z poszczególnymi podwykonawcami, samemu koordynując logistykę dotyczącą inwestycji deweloperskiej [Goldiszewicz, 2012, 51].

Interesującą kwestią jest przypadek własności nieruchomości, na której ma być zrealizowane przedsięwzięcie deweloperskie. W wypadku jedynego właściciela, którym będzie przedsiębiorca na podstawie art. $43^{1}$ k.c. sprawa wydaje się jasna i oczywista, że to on jest stroną umowy deweloperskiej. Jednakże z przepisów jasno nie wynika, że deweloper musi być w momencie powstania zobowiązania właścicielem gruntu, na którym będzie zrealizowane przedsięwzięcie [Wszołek, 2013, 37]. K. Maj stwierdza, że w momencie powstania nie jest istotne, czy deweloper w tym momencie jest właścicielem danej nieruchomości. Celem umowy jest przeniesienie prawa własności na przyszłego nabywcę, więc de facto mógłby nabyć własność przed terminem przeniesienia praw na nabywcę, określonym umownie między stronami [Maj, 2012, 135]. R. Strzelczyk przeciwstawia się takiemu podejściu, zarzucając, że takie postanowienia umowne naruszyłyby zasadę nemo plus iuris ad aliu transfere potest quam ipse habet [Strzelczyk, 2013, 135]. Zauważyć należy jednak, że umowa deweloperska w swojej czystej postaci jest umową zobowiązującą, a nie rozporządzającą, a do umów tego drugiego typu tę zasadę 
się stosuje [Wilk, 2011, 20D]. Co innego, gdy nieruchomość stanowi przedmiot współwłasności zarówno dewelopera, jak i innych podmiotów prawa. Zgodnie z polskim prawem w tym przypadku wymagana jest zgodna wszystkich współwłaścicieli co do kwestii rozporządzenia współwłasnością. W wypadku braku jednomyślności lub też przypadku, gdy udziały w nieruchomości nie przekraczają 50 procent, należy odnieść się do art. 199 k.c., uprawniającego sąd do rozstrzygnięcia tego sporu, w wypadku wystąpienia zainteresowanego podmiotu lub podmiotów z takim żądaniem [Strzelczyk, 2013, 135]. Drugim przypadkiem spornym co do własności nieruchomości jest współwłasność majątkowa małżeńska. Zgodnie z przepisami Art. 37 § 1 pkt 1 k.r.o. do zbycia nieruchomości (do czego dochodzi de facto przy przeniesieniu prawa własności lokalu mieszkalnego lub domu jednorodzinnego na nabywcę) wymagana jest zgoda obu małżonków [Ustawa z dnia 25 lutego 1964 r. - Kodeks rodzinny i opiekuńczy, Dz.U. 1964 nr 9 poz. 59 ze zm.]. Brak takiej zgody będzie miał wpływ na doniosłość prawną i ważność takiego kontraktu, a uzależniony będzie, na podstawie art. 37 § 2 k.r.o., od przyszłego potwierdzenia przez małżonka dewelopera. Umowa tego typu, mimo takiego obowiązku ustawowego, będzie miała skutki prawne jedynie wobec samego dewelopera, bez wpływu na małżonka [Strzelczyk, 2013, 135].

Zagadnieniem poruszanym w piśmiennictwie jest możliwość zastosowania przepisów ustawy deweloperskiej do działalności spółdzielni mieszkaniowej i potraktowanie jej jako dewelopera. R. Tymiec stwierdza, że przepisy regulujące ochronę nabywców lokali mieszkalnych można zastosować w przypadku, gdy dodatkową działalnością spółdzielni jest budowanie lub nabywanie budynków w celu sprzedaży znajdujących się w nich lokali mieszkalnych, na podstawie art. 1 ust. 2 pkt 5 ustawy o spółdzielniach mieszkaniowych [Ustawa z dnia 15 grudnia 2000 r. o spółdzielniach mieszkaniowych , Dz.U. $2001 \mathrm{nr} 4$ poz. 27.] w sytuacji, gdy z nabywcami będą zawierane umowy spełniające przesłanki umowy deweloperskiej. Wiadomym jest, że podstawowym założeniem istnienia spółdzielni mieszkaniowej, zgodnie z art. 1 ust. 1 w zw. z art. 1 ust. 2 pkt 13 [Ustawa z dnia 15 grudnia 2000 r.] zaspokajanie potrzeb mieszkaniowych jej członków oraz ich rodzin, a w tej kwestii ustawa deweloperska zastosowania mieć nie będzie [Okolski (red.), 2015, 618-622]. Zdanie te podziela również R. Strzelczyk, dodając, że działalność 
podlegająca reżimowi ustawy deweloperskiej powinien być uwzględniony w statucie spółdzielni [Strzelczyk, 2013, 135]. B. Gliniecki uzależnia zastosowanie tej regulacji prawnej od kręgu nabywców, wobec których spółdzielnia mieszkaniowa skieruje swoją ofertę. Gdy takimi podmiotami będą inne osoby fizyczne niż członkowie tej spółdzielni, to na podstawie art. 1 ust. 2 pkt 5 oraz art. 1 ust. 6 [Ustawa z dnia 15 grudnia 2000 r.] w związku z art. 3 pkt 4 [Ustawa z dnia 16 września 2011], będzie możliwość sięgnięcia do rygoru ustawowego ustawy deweloperskiej [Gliniecki, 2012, 41].

Zauważalną tendencją w budownictwie mieszkaniowym jest fakt, że działalność deweloperska najczęściej prowadzona jest w formie spółek regulowanych przez prawo handlowe. Najczęściej są nimi przedsiębiorcy budowlani, którzy istnieją od lat na rynku mieszkaniowym, mając tym samym doświadczenie w tym sektorze gospodarki. Swoją działalność opierają na realizacji obiektów mieszkaniowych, zazwyczaj w charakterze generalnych wykonawców. Obecnie zauważalne jest coraz częstsze występowanie w roli deweloperów podmiotów typu biura projektowe, biura pośrednictwa obrotu nieruchomościami, agencje inwestycyjno-budowlane [Nowacki, 2005, 30-34], które nie posiadając wystarczające zaplecza wykonawczego, zlecają gro czynności o takim charakterze podmiotom zewnętrznym.

\section{Nabywca lokalu mieszkalnego lub domu jednorodzinnego jako strona umowy deweloperskiej}

Drugą stronę umowy deweloperskiej stanowią nabywcy, którym zgodnie art. 3 ust. 4 [Ustawa z dnia 16 września 2011] może być „osoba fizyczna, która na podstawie umowy deweloperskiej uprawniona jest do ustanowienia przeniesienia na nią prawa odrębnej własności lokalu mieszkalnego albo nieruchomości zabudowanej domem jednorodzinnym, która zobowiązuje się do spełnienia świadczenia pieniężnego na rzecz dewelopera" [Ustawa z dnia 16 września 2011]. Na podstawie tej definicji można wywnioskować, że nabywcą w świetle ustawy deweloperskiej może być jedynie osoba fizyczna. Wyłączone są zarówno osoby prawne, jak i jednostki organizacyjne na podstawie art. $33^{1}$ k.c. Kolejnym faktem, zauważalnym przy analizie przepisów ustawy deweloperskiej, jest nieuwzględnienie przez ustawodawcę konsumenta jako nabywcy w umowie deweloperskiej. Zastosowany jest szerszy 
katalog osób fizycznych, w którym zawierają się zarówno podmioty nieprofesjonalne w postaci konsumentów, jak i profesjonalne w postaci przedsiębiorców będących osobami fizycznymi [Czech, 2013, 42-43]. Regulacja o takim charakterze jest o tyle specyficzna, że w przypadku konsumentów ochrona ustawowa jest uzasadniona, co w przypadku przedsiębiorców stanowi instrument faworyzowania strony nabywczej, mimo założenia o równości stron w obrocie profesjonalnym [Szymańczyk (red.), 2014, 55-57]. Poza tym przedsiębiorca nabywający prawo odrębnej własności lokali w zakresie swojej działalności gospodarczej może wprowadzać to prawo w dalszy obrót na rynku mieszkaniowym na podstawie klasycznej umowy sprzedaży nieruchomości lub umowy najmu. Taka konstrukcja prawna w postaci objęcia katalogiem przepisów chroniących nabywców wszystkie osoby fizyczne, stanowi swoistego rodzaju nadinterpretację ustawodawcy, wynikającą z postanowienia sygnalizacyjnego Trybunału Konstytucyjnego [Postanowienie Trybunału Konstytucyjnego z dnia 2 sierpnia 2010 r, sygn. S 3/10, OTK-B, 2010, Nr 6, poz. 407], w którym rodzimy sąd konstytucyjny jasno zakomunikował władzy ustawodawczej niekonstytucyjność wynikającą z braku ochrony ustawowej „osób fizycznych, będących kontrahentami deweloperów" [Strzelczyk, 2013, 134].

W obecnym reżimie prawa polskiego podmioty występujące jako nabywca w umowie deweloperskiej w charakterze konsumentów podlegają ochronie prawnej wynikającej z dwóch podstaw prawnych. Z jednej strony będzie to ustawa o ochronie nabywcy lokalu mieszkalnego i domu jednorodzinnego, stanowiąca niejako podstawę stosunków deweloperskich. Drugim aktem prawnym będzie natomiast Ustawa z dnia 16 lutego 2007 r. o ochronie konkurencji i konsumentów (Dz. U. 2007 nr 50 poz. 331). W momencie zawierania umowy obowiązkiem notariusza powinno być odnotowanie w jej treści, kim jest przyszły nabywca prawa własności - konsumentem lub przedsiębiorcą, ze względu na doniosłość prawną w kontekście możliwości zastosowania reżimu prawnego wcześniej wymienionych aktów prawnych w przypadku ochrony praw nabywcy [Strzelczyk, 2013, 134].

Kolejnym problemem godnym poruszenia, podobnie jak przy deweloperze, jest kwestia małżeństwa występującego po stronie nabywczej w umowie deweloperskiej. Ze względu na charakter czynności, której skut- 
kiem będzie odpłatne nabycie nieruchomości lub użytkowania wieczystego, zgoda na takie działania powinna być wyrażona przez obu małżonków za pomocą złożenia podpisu na umowie deweloperskiej, na podstawie art. $37 \S$ 1 [Ustawa z dnia 25 lutego 1964 r.] Brak takiej zgody będzie przesłanką do bezskuteczności zawieszonej umowy deweloperskiej [Pietrzykowski (red.), 2015, 302-304], która może wystąpić w sytuacji, gdy jeden z małżonków podpisał umowę, drugi natomiast tego jeszcze nie potwierdził. W wypadku niepotwierdzenia umowy deweloperskiej staje się ona nieważna [Wyrok Sądu Najwyższego z dnia 9 marca 2004 r., I CK 436/03, Legalis nr 272445]. Zgody jednak nie będzie wymagał przypadek, gdy jeden z małżonków będzie występował jako pełnomocnik drugiego małżonka. Obecny przy zawarciu umowy deweloperskiej mąż lub żona będzie występować zarówno w imieniu własnym, jak i współmałżonka lub współmałżonki nieobecnej przy tej czynności prawnej [Strzelczyk, 2013, 141].

Należy jednak stwierdzić, że taka sytuacja będzie miała miejsce w przypadku, gdy między mężem i żoną występować będzie majątek wspólny. Wynika to również z faktu doniosłości takiego zdarzenia w życiu każdej rodziny, przez co ustawodawca zobligował strony stosunku małżeńskiego do współdziałania w tej kwestii [Strzebińczyk, 2004, 88-102] Rozdzielność majątkowa i brak podpisu drugiego małżonka nie mają wpływu na doniosłość prawną umowy deweloperskiej, gdyż każdy z małżonków zarządza swoim oddzielnym majątkiem.

W doktrynie poruszany jest problem nietrafnego, a nawet wadliwego zdefiniowania nabywcy w ustawie deweloperskiej. Ten aspekt regulacji prawnej należy odnieść do wcześniej analizowanego katalogu nabywców odrębnych praw własności lokali mieszkalnych lub domów jednorodzinnych. Nie jest jasnym uprzywilejowanie osób fizycznych występujących w charakterze przedsiębiorców, a z samego uzasadnienia do tej ustawy wynika, że miała ona chronić stricte konsumentów, nieprofesjonalnych uczestników rynku mieszkaniowego [Uzasadnienie do ustawy z dnia 16 czerwca 2011 r. o ochronie praw nabywcy lokalu mieszkalnego lub domu jednorodzinnego, Druk Sejmowy nr 4349, Warszawa 2011]. Cytując wprost uzasadnienie postanowienia Trybunału Konstytucyjnego z 2 sierpnia 2010 r. widoczne jest, że „po jednej stronie występuje nabywca mieszkania - konsument, po drugiej 
zaś deweloper, czyli profesjonalny uczestnik obrotu gospodarczego" [Postanowienie Trybunału Konstytucyjnego z dnia 2 sierpnia 2010 r., sygn. S 3/10, OTK-B, 2010, Nr 6, poz. 407]. Samo dychotomiczne rozróżnienie tych dwóch terminów, zwłaszcza w jednym zdaniu, stwierdzającym, że to właśnie jedną stroną jest podmiot profesjonalny, a drugą nieprofesjonalny powinno dać do myślenia ustawodawcy, że właśnie takim zakresem terminowym powinien objąć podmioty zawierające umowę deweloperską [Burzak, Okoń, Pałka, 2012, 72]. W pierwotnych projektach ustawy termin "konsument” był zamiennie stosowany wraz z "nabywcą”, jednakże w finalnej wersji przekazanej do trybu legislacyjnego zrezygnowano z pierwszego pojęcia, nie dając temu ani podstaw faktycznych, ani nie uwzględniając w ratio legis [Pawlak, 2012, 1314-1315].

\section{Podsumowanie}

Problematyka dotycząca zarówno stron umowy deweloperskiej, jak i samej umowy deweloperskiej jest bardzo aktualna. Rozwój budownictwa mieszkaniowego w Polsce ma olbrzymie tempo i na co dzień widoczne są pojawiające się nowe inwestycje na tym rynku. O ile zdefiniowanie dewelopera nie powinno sprawić trudności, stosując zarówno przepisy ustawy deweloperskiej, jak i innych aktów prawnych, o tyle kwestia dotycząca nabywcy stanowi podstawę do dalszych rozważań. Nie wiadomo, dlaczego ustawodawstwa pokusił o zaliczenie do kręgu nabywców wszystkie osoby fizyczne, zarówno będące konsumentami, jak i prowadzące jednoosobową działalność gospodarcza, ewidencjonowaną w CEiDG. Osobiście uważam, że stanowi to błąd interpretacyjny ustawodawcy, próbującego zrealizować założenia zawarte w uzasadnieniu postanowienia sygnalizacyjnego Trybunału Konstytucyjnego [Postanowienie Trybunału Konstytucyjnego z 2 sierpnia 2010 r.], będące podstawą regulacji umowy deweloperskiej w polskim systemie prawa. Cytując wprost uzasadnienie Trybunału Konstytucyjnego z 2 sierpnia 2010 r., widoczne jest, że „po jednej stronie występuje nabywca mieszkania - konsument, po drugiej zaś deweloper, czyli profesjonalny uczestnik obrotu gospodarczego". Samo dychotomiczne rozróżnienie tych dwóch terminów, zwłaszcza w jednym zdaniu, stwierdzającym, że to właśnie jedną stroną jest podmiot profesjonalny, a drugą nieprofesjonalny powinno dać do myślenia 
ustawodawcy, że właśnie takim zakresem terminowym powinien objąć podmioty zawierające umowę deweloperską, a obecnie powinien on dokonać nowelizacji przedmiotowo istotnego aktu prawnego w tym zakresie.

\section{Bibliografia}

Adamska-Sałaciak A., Nowy słownik Fundacji Kościuszkowskiej, Wyd. Universitas, Kraków 2003.

Burzak A., Okoń M., Pałka P., Ochrona praw nabywcy lokalu mieszkalnego lub domu jednorodzinnego. Komentarz, Warszawa 2012.

Czech T., Ustawa deweloperska. Komentarz, Warszawa 2013.

Gliniecka B., Ustawa deweloperska. Komentarz do ustawy oeochroniw nabywcy lokalu mieszkalnego lub domu jednorodzinnego, Warszawa 2012.

Gniewek E. (red.), Gniewek E., Kodeks cywilny. Komentarz, Warszawa 2016.

Goldiszewicz A., Treść i charakter umowy deweloperskiej, Warszawa 2012.

Katner W. J., Podstawowe zagadnienia prawne nowej ustawy o swobodzie działalności gospodarczej, „Przegląd Prawa Handlowego” 2014, nr 12.

Kidyba A., Kodeks spółek handlowych. Tom 1. Komentarz do art. $1-300$ k.s.h., Warszawa 2015.

Kidyba A., Prawo handlowe, Warszawa 2012.

Kohutek K., Kuglarz P. Projekt ustawy o zasadach finansowania inwestycji mieszkaniowych - funkcje oraz mechanizmy stosowania wprowadzanych instytucji, „Przegląd Ustawodawstwa Gospodarczego" 2004, nr 9.

Maj K., Praktyczne aspekty umowy deweloperskiej w rozumieniu Ustawy o ochronie praw nabywcy lokalu mieszkalnego lub domu jednorodzinnego, „Rejent” 2012, nr 10.

Nowacki P., Deweloper jako organizator i wykonawca budownictwa mieszkaniowego, „Nieruchomości” 2005, nr 9.

Okolski D. (red.), Tymiec R., Ustawa o ochronie praw nabywcy lokalu mieszkalnego lub domu jednorodzinnego. Komentarz [w:] Prawo budowlane i nieruchomości. Komentarz, Warszawa 2015.

Pawlak B., Uwagi o zakresiel zakresie obowiązywania Ustawy z 16.09.2011 r. o ochronie nabywcy lokalu mieszkalnego lub domu jednorodzinnego, „Monitor Prawniczy" 2012, nr 24.

Pietrzykowski K. (red.), Pietrzykowski K., Kodeks rodzinny i opiekuńczy. Komentarz, Warszawa 2015. 
Pyziak-Szafnicka M. (red.), Katner W. J., Kodeks cywilny. Część ogólna. Komentarz, Warszawa 2014.

Safjan M. (red.), Frąckowiak J., System prawa prywatnego. Tom I. Prawo cywilne część ogólna, Warszawa 2012.

Strzebińczyk J., Nowelizacja przepisów kodeksu rodzinnego i opiekuńczego w zakresię małżeńskiego prawa majątkowego. Cz. 2, „Rejent” 2004, nr 9.

Strzelczyk R., Umowa deweloperska w systemie prawa prywatnego, Warszawa 2013. Szymańczyk A. (red.), Mamcarz A., Umowa deweloperska w praktyce, Warszawa 2014.

Trzaskowski R., Działalność gospodarcza w rozumieniu przepisów prawa cywilnego na tle orzecznictwa, „Glosa” 2006, nr 2.

Wilk A., Nowa regulacja umowy deweloperskiej, „Radca Prawny” 2011, nr 120.

Wszołek J., Porzucowny projekt ustawy deweloperskiej i jego postanowienia, „Nieruchomości" 2011, nr 2.

Wszołek J., Umowa deweloperska, zagadnienia praktyczne, Warszawa 2013.

\section{Akty prawne}

Ustawa z dnia 25 lutego 1964 r. - Kodeks rodzinny i opiekuńczy, Dz.U. 1964 nr 9 poz. 59 ze $z m$.

Ustawa z dnia 15 grudnia 2000 r. o spółdzielniach mieszkaniowych, Dz.U. 2001 nr 4 poz. 27.

Ustawa z dnia 16 lutego 2007 r. o ochronie konkurencji i konsumentów, Dz.U. 2007 nr 50 poz. 331.

Ustawa z dnia 16 września 2011 r. o ochronie praw nabywcy lokalu mieszkalnego lub domu jednorodzinnego, Dz.U. 2011 nr 232 poz. 1377 ze zm.

Uzasadnienie do Ustawy z dnia 16 czerwca 2011 r. o ochronie praw nabywcy lokalu mieszkalnego lub domu jednorodzinnego, druk sejmowy nr 4349, Warszawa 2011.

\section{Orzecznictwo}

Uchwała Sądu Najwyższego z 14 maja 1998 r., Sygn. III CZP 12/98, OSNC 1998, nr 10, poz. 151.

Wyrok Sądu Najwyższego z dnia 9 marca 2004 r., Sygn. I CK 436/03, Legalis nr 272445.

Postanowienie Trybunału Konstytucyjnego z dnia 2 sierpnia 2010 r., Sygn. S 3/10, OTK-B, 2010, nr 6, poz. 407. 


\section{Źródła internetowe}

Dedinicja słowa „deweloper” HTTP://SJP.PWN.PL/SZUKAJ/DEWELOPER.HTML (dostęp 04.06.2018 r.). 